\title{
Dentigerous cyst in the maxillary posterior region associated with an impacted deciduous molar
}

\author{
Cisto dentigero em região posterior da maxila associado a molar decíduo incluso
}

\author{
Érica Passos de Medeiros LACERDA ${ }^{1}$ \\ (iD) ORCID iD 0000-0002-0277-6190 \\ Sérgio Bartolomeu de Farias MARTORELLI² \\ (D) ORCID iD 0000-0002-0251-1475 \\ Fernando de Oliveira MARTORELLI ${ }^{3}$ \\ (iD) ORCID iD 0000-0001-7985-4639
}

\begin{abstract}
Dentigerous cyst, ranked the second most common developmental odontogenic cyst of the jaws after the radicular cyst, is a well-defined, unilocular radiolucent lesion without symptoms, frequently noted as an incidental finding in routine radiographs. The cystic lining is derived from epithelial remanants of the tooth-forming organ and the teeth most commonly affected are impacted mandibular third molars and permanent maxillary canines. While the dentigerous cyst is not uncommon, its development as a result of an impacted deciduous tooth is rare. The aim of this article was to make a brief literature review and report a case of dentigerous cysts associated with an impacted deciduous molar in the maxillary posterior region, with involvement of the right maxillary sinus.
\end{abstract}

Indexing terms: Surgery oral. Dentigerous cyst. Odontogenic cyst. Deciduous teeth

\section{RESUMO}

Cisto dentígero é o segundo cisto odontogênico maxilar de desenvolvimento mais comum, depois do cisto radicular. É uma lesão radiolúcida, bem definida, unilocular, sem sintomatologia e frequentemente apontada como um achado acidental em radiografias de rotina. O conteúdo cístico é derivado de remanescentes epiteliais do órgão formador dentário e os dentes mais comumente afetados são terceiros molares inferiores impactados e caninos superiores permanentes. Embora o cisto dentígero não seja incomum, o seu desenvolvimento como resultado de um dente decíduo impactado é raro. Este artigo teve por objetivo realizar uma breve revisão da literatura e relatar um caso de cisto dentígero associado a um molar decíduo incluso na região posterior da maxila com íntima relação com o seio maxilar direito.

Termos de indexação: Cirurgia bucal. Cisto dentigero, Cistos odontogênicos. Dente decíduo.

\section{INTRODUCTION}

Among the developmental cysts in the maxillofacial region, the dentigerous cyst is ranked the second most common after the radicular cyst [1-3]. The term dentigerous means "containing a tooth", and this is the characteristic description of this cyst [4]. The cystic content is derived from epithelial remnants of the toothforming organ and the teeth most commonly affected are impacted mandibular third molars and permanent maxillary canines, mandibular premolars, followed by supernumerary teeth and central incisors, in decreasing frequency of involvement [5-7]. Teeth in a mesial position are occasionally reported in approximately $5 \%$ of all dentigerous cysts [8]. However, the occurrence of a dentigerous cyst associated with a deciduous tooth is a rare phenomenon [9-14].

The majority of patients with dentigerous cysts present no painful symptomatology, unless there is an exacerbated inflammatory process. Generally, they are

\footnotetext{
${ }^{1}$ Consultório particular. Rua Irmã Maria David, 155, 52061070, Casa Forte, Recife, PE, Brasil. Correspondência para / Correspondence to: EPM LACERDA. E-mail: < ericapassos@gmail.com>.

${ }^{2}$ Faculdade de Odontologia do Recife. Recife, PE, Brasil.

${ }^{3}$ Consultório particular. Recife, PE, Brasil.

$\boldsymbol{v} \boldsymbol{v}$

Como citar este artigo / How to cite this article

Lacerda EPM, Martorelli SBF, Martorelli FO. Dentigerous cyst in the maxillary posterior region associated with an impacted deciduous molar. RGO, Rev Gaúch Odontol. 2018;66(2):00-00. http://dx.doi.org/10.1590/1981-8637201800020000153279
} 
identified in routine radiographic exams $[15,16]$.

Radiographically, the dentigerous cyst is shown as a well-defined radiolucent lesion, surrounding an impacted tooth, and frequently had a sclerotic border [15].

There are two types of dentigerous cysts: the developmental type, which is generally found in the late first and second decades of life. This occurs in mature teeth, generally without inflammation; and the inflammatory type that is found in the first and second decades of life. It commonly occurs in immature, non-vital deciduous teeth, or another source of propagation that involves the tooth follicle [17].

The treatment indicated for the dentigerous cyst depends on the size of the lesion. Irrespective of their localization, dentigerous cysts are frequently treated surgically, either by enucleation or marsupialization [18].

Deciduous teeth by chance associated with dentigerous cysts are uncommon. This article reports the case of a dentigerous cyst that affected a 17-year-old patient, associated with a deciduous molar in the maxillary posterior region, in a close anatomic relationship with the right maxillary sinus.

\section{CASE REPORT}

The patient, a 17-year-old Caucasian man, sought treatment at the Oral Maxillofacial Surgery and Traumatology Center of the Pernambuco state employee care service ("Serviço de Assistência ao Servidor do Estado de Pernambuco - SASSEPE - IRH Governo do Estado de Pernambuco") of the Pernambuco State Government, Brazil. He was referred by his orthodontist for treatment of a lesion in the posterior region of the left maxilla, accidentally discovered by routine radiographic exam.

During anamnesis, the patient did not mention any complaints of painful symptomatology in the affected region, or any other type of discomfort. He reported no episode of trauma in the region.

On physical exam, the patient presented facial symmetry, absence of swelling in the cervicofacial chain of ganglia and normal oral mucosa color. No increase in extra-oral volume of intraoral expansion was observed in the region involved. Intraorally, the pulp test confirmed that all the teeth related to this lesion were vital. Moreover, there was no painful symptomatology on percussion, or any signs of pathological mobility.

The panoramic radiographic exam of the maxilla sent by the orthodontist who referred him revealed an impacted maxillary right deciduous second molar associated with a radiolucent image, measuring approximately $2.0 \times 1.5 \mathrm{~cm}$. The roots of teeth 14 and 15 were also noted to be divergent. The lesion extended between the roots of the permanent maxillary teeth (maxillary right second premolar 15, and the maxillary right first molar 16, and in a superior direction to the right maxillary sinus) (Figure 1).

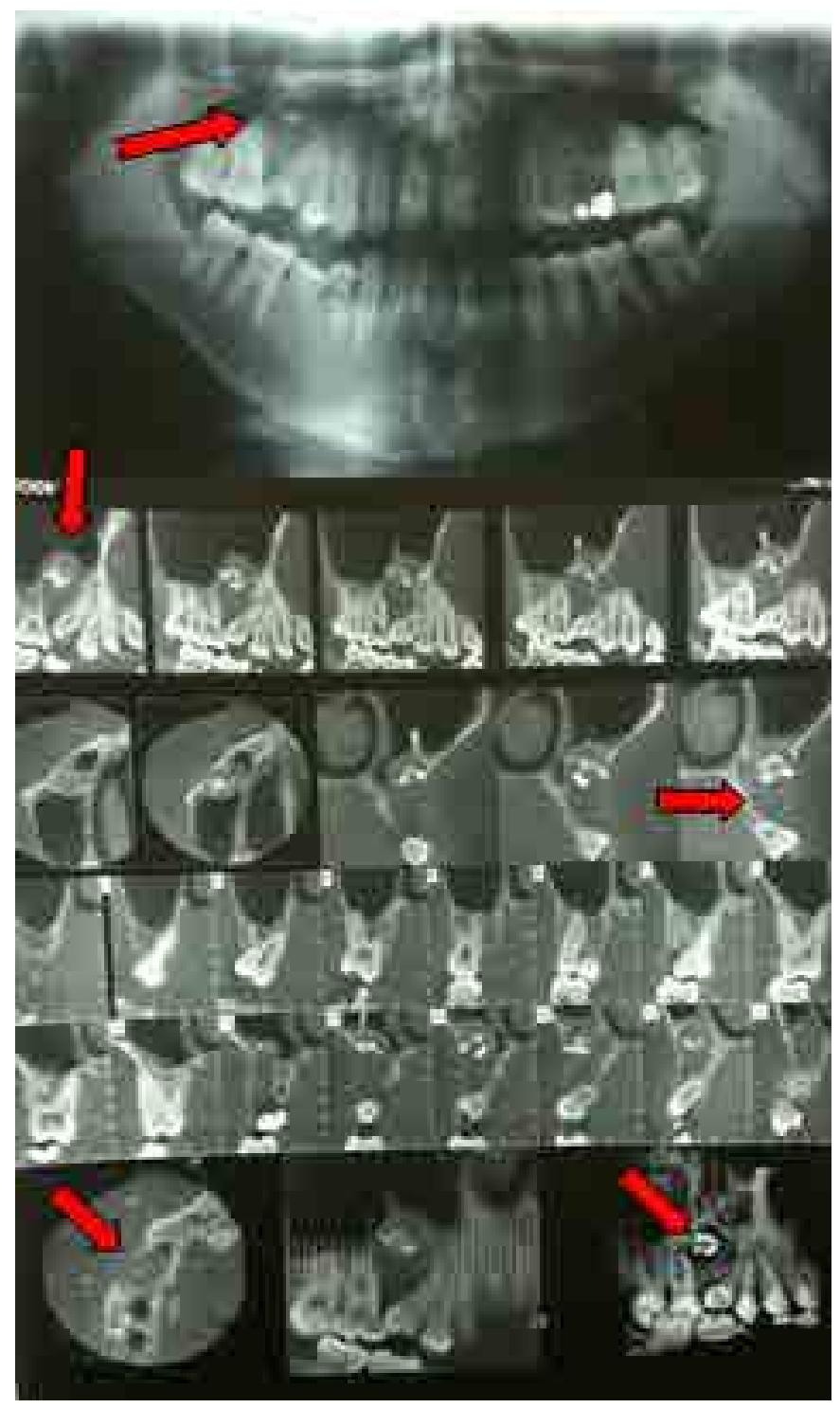

Figure 1. Panoramic radiograph and computed tomograph in lateral and axial cuts: impacted tooth 55 associated with the radiolucent cystic lesion.

The computed tomographic image showed a lesion that extended to the maxillary sinus, without evident signs of compromise of this portion, due to the 
lack of symptomatology reported by the patient. The other extensions of the space ((Antrum of Higmore) without hidden indications (Figure 1).

After the clinical and radiological exams, the diagnostic hypothesis was a dentigerous cyst related to the impacted deciduous tooth. Therefore, routine preoperative exams were requested for surgery under general anesthetic, the results of which were found within the patterns of normality. Therefore, the surgery proposed was surgical excision by enucleation of the lesion.

Under general anesthesia and left nasotracheal intubation, antisepsis of the facial and cervical regions was performed with a $2 \%$ chlorhexidine solution, and of the oral cavity with an equal solution at the concentration of $0.12 \%$. The operative field was positioned and after oropharyngeal buffering a peripheral subperiosteal infiltration was performed with $0.5 \%$ bupivacaine containing epinephrine. After this, an intrasulcular incision was made with a 15 scalpel, in the region of the right maxilla, which extended from tooth 12 up to the region of tooth 16 , where a relaxing incision with divulsion in the distal direction was performed, at an angle of $45^{\circ}$ (Figure 2).

With the use of a periosteal elevator, mucoperiosteal displacement of the incised region was performed, exposing the entire vestibular cortical bone (Figure 2). After this stage, and separation of the mucoperiosteal flap, the exposed vestibular cortical plate was found to be very thin and partially perforated in thee impacted molar region. The cystic capsule was identified after removing the thin vestibular cortical bone. The cystic capsule was carefully separated from the bone subjacent to the impacted tooth (Figure 2).

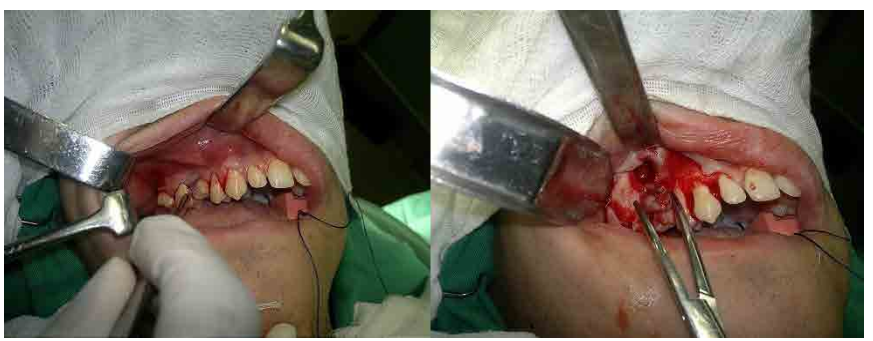

Figure 2. Incision, removal of the cystic capsule and impacted tooth.

The lesion involving the anterior wall of the right maxillary sinus was identified, and measured 2.0 $x 1.5 \mathrm{~cm}$. After complete enucleation of the lesion, and simultaneous removal of the impacted deciduous tooth
(Figure 3) perforation of the anterior wall of the sinus was inevitable.

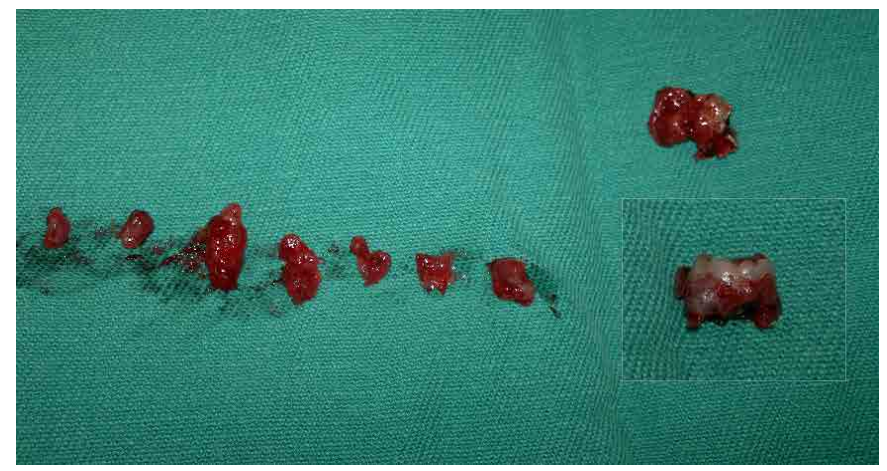

Figure 3. Macroscopic aspect of the surgical part.

After regularizing the osteotomies with bone finishing burs, the wound was cleaned, irrigation/aspiration of the maxillary antrum was performed, the anterior wall of the maxillary sinus and post-enucleation bone deformity were repaired with the use of a sterile, absorbable, hemostatic material - Surgicel ${ }^{\mathrm{Tm}}$, in the presentations of a screen and fibrin sponge - Gelfoam ${ }^{\mathrm{T}}$, respectively, with the purpose protecting the right maxillary sinus that was trans-surgically exposed. In sequence, occlusive suturing and mucosal sealing were performed with Polyglactin 910 Suture (VicrylTM 3-0) (Figure 4).

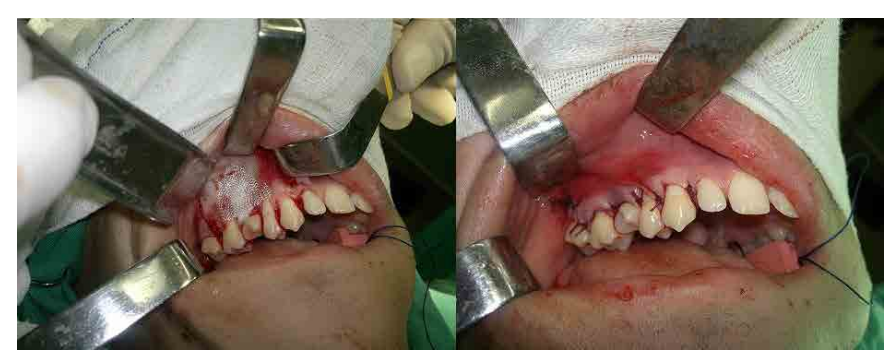

Figure 4. Filled bone cavity, maintaining the integrity of the sinus wall and suture.

The following antibiotic medication was prescribed (Cefadroxil 500mg - every12 hours for 07 days) / Anti-inflammatory (Nimesulide 100mg - every 12 hours for 06 days) / Analgesic (Dipyrone 500mg - every 6 hours for 03 days) for the post-operative period that proceeded without any abnormality. The patient recovered without any intercurrences. The suture was removed on the 10th day post-operatively, and checked with a control post-operative Panoramic Radiograph, that showed excellent bone remodeling, with almost complete bone neoformation at the surgical site (Figure 5 . 


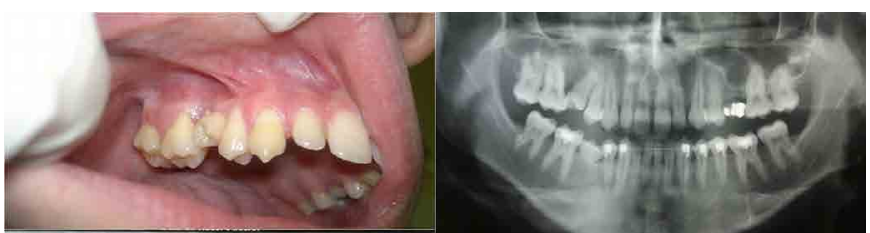

Figure 5. A) clinical aspect in post-operative period at 30 days; b) radiographic aspect in post-operative period at 30 days

Histological exam of the specimen confirmed the diagnosis of Dentigerous Cyst.

The patient was followed-up in the post-surgical period at 6 months, without any complication reported, with complete bone neoformation shown in the operated region (Figure 6).

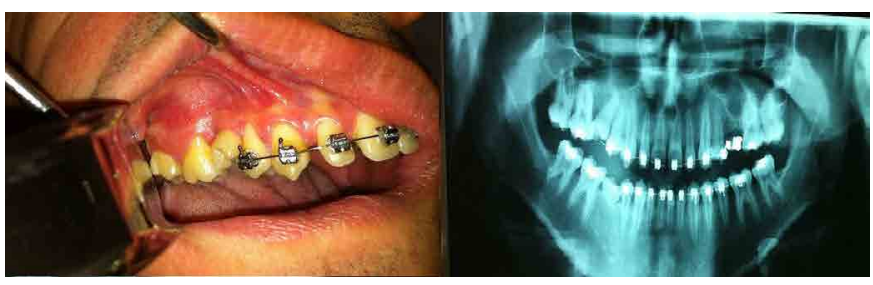

Figure 6. A) clinical aspect in post-operative period at 6 months; b) radiographic aspect in post-operative period at 6 months

\section{DISCUSSION}

The development of a dentigerous cyst in association with impacted permanent teeth is not uncommon, whereas, its development as the result of noneruption of deciduous teeth is rare Yamanaka et al. [9], Kishimoto et al. [12], Kusukawa et al. [13], Rosenlicht et al. [14], Bharath et al. [15]. This coincides with this report and that of Michael et al. [10], who reported a study, (in addition to the fourth case exposed in the literature, similar to ours), of a dentigerous cysts that developed as a radiolucent lesion associated with an impacted maxillary deciduous molar, which emphasizes the relevance and rarity of this article.

This clinical case report corroborates the principle that cystic enucleation is the recommended treatment for small-sized cysts, however, there are controversies where cysts of large proportions are concerned, which may, according to Neville et al. [20], be treated by endodontic procedures in the teeth involved, associated with marsupialization, decompression or fenestration.

Differently from the study under discussion, in which the option was to preform enucleation as the treatment of choice, marsupialization was the treatment of choice in another six articles found in the literature, namely Yamanaka et al. [9], Kishimoto et al. [12], Kusukawa et al. [13], Rosenlicht et al. [14], Bharath et al. [15] Yu-hsuan hu et al. [17], Tüzüm et al. [22], to preserve the permanent tooth involved in the lesion. This decision was based on the patient's age and the strategic function of the tooth involved, since the patient followed-up the occurrence of its eruption. Once again, this was in disagreement with the report here presented, bearing in mind that in the present case there was no possibility of the impacted tooth erupting, because it concerned a deciduous tooth without eruptive force at the patient's age of 17 years. Moreover, it was impacted between the roots of the right second premolar and first molar.

Damante et al. [19], defended the use of bone biomaterials in the management of residual bone cavities, to reduce the risks of bone fragility and shorten the postenucleation period of bone recovery. This understanding coincided with the article here presented, seeing that biomaterials were used (fibrin sponge and oxidized cellulose), as a means of promoting primary closure of the bone recess and maintenance of the sinus wall integrity.

In this case report, there was reduction in the residual cavity size, and gradual increase in bone density, which were identified in the post-operative control radiograph at 6 months, similarly to the studies of Zakirulla et al. [2] and Shokier and Khalifa et al. [21], whose patients - children and adolescents - had good postsurgical neoformation of the bone defect, thanks to the great propensity for bone regeneration they had.

\section{CONCLUSION}

In view of the case presented, the authors concluded that the development of dentigerous cysts associated with impacted permanent teeth is extremely rare, with few cases related in the literature; and that cases related to impacted deciduous teeth are also rare. The treatment of choice in cases of non-voluminous dentigerous cysts associated with impacted deciduous teeth is enucleation of the lesion and excision of the deciduous tooth involved.

\section{Collaborators}

We verified that all the authors had an effective participation in the elaboration of the article (Summary, Introduction, Literature Review, Discussion and Conclusion), as well as participated as assistants in the surgery of the clinical case. 


\section{REFERENCES}

1. Mamatha NS, Krishnamoorthy B, Savitha JK, Pankaja BHA. Diagnostic CBCT in Dentigerous Cyst with Ectopic Third Molar in the Maxillary Sinus-A Case Report. J Clin Diagn Res. 2014 Jun; 8(6): ZD07-ZD09.

2. Zakirulla M, Yavagal CM, Jayashankar DN, Allanbajsh $M$. Dentigerous cyst in children: a case report and outline of clinical management for pediatric and general dentists. J Orofac Res. 2012;2(4):238-242.

3. Narsapur SA, Chinnanavar SN, Choudhari SA. Radicular cyst associated with deciduous molar: A report of a case with an unusual radiographic presentation. Indian J Dent Res. 2012 JulAug;23(4):550-3. doi: 10.4103/0970-9290.104970

4. Hasan S, Ahmed SA, Reddy LB. Dentigerous cyst in association with impacted inverted mesiodens: Report of a rare case with a brief review of Literature. Int J Appl Basic Med Res. 2014 Sep;4(Suppl 1):S61-4. doi: 10.4103/2229-516X.140748

5. John T, Shekhar MG, Koshy M. Dentigerous cyst associated with supernumerary teeth: A report of three cases. BMJ Case Rep. 2013;2013: bcr2012008329.

6. Bhat S, Vidhya MB, Sargod SC. Radicular cyst associated with endodontically treated deciduous tooth: a case report. J Indian Soc Pedod Prev Dent. 2003 Dec;21(4):139-41.

7. Shibata Y, Asaumi J, Yanagi Y, Kawai N, Hisatomi M, Matsuzaki $\mathrm{H}$, et al. Radiographic examination of dentigerous cysts in the transitional dentition. Dentomaxillofac Radiol. 2004 Jan;33(1):17-20.

8. Dinkar AD, Dawasaz AA, Shenoy S. Dentigerous cyst associated with multiple mesiodens: a case report. J Indian Soc Pedod Prev Dent. 2007 Mar;25(1):56-9.

9. Yamanaka T, Sawakuma Y, Wakae H, Toyoshima S, Tomioka T. A case of foliicular cyst probably due to a deciduous tooth. Jpn J Oral Surg. 1977;23(3):370-4.

10. Boyczuk MP, Berger JR, Lazow SK. Identifying a deciduous dentigerous cyst. J Am Dent Assoc. 1995 May;126(5):643-4.

11. Agrawal M, Raghavendra PDS, Singh B, Agrawal N. Multiple teeth in a single dentigerous cyst follicle: A perplexity. Ann Maxillofac Surg. 2011 Jul;1(2):187-9. doi: 10.4103/22310746.92792
12. Kishimoto $H$, Harada $T$, Yoshimura $Y$. Follicular cyst originated from deciduous molar in a 5-month-old infant: report of a case. Jpn J Oral Surg. 1988;34:1394-8.

13. Kusukawa J, Lie K, Morimatsu M, Koyanagi S, Kameyama T. Dentigerous cyst associated with a deciduous tooth. Oral Surg Oral Med Oral Pathol. 1992 Apr;73(4):415-8.

14. Rosenlicht J, Murohv JB, Malonev PL. Fetal alcohol svndrome. Oral Med Oral Patol. 1979;47(1):8-10.

15. Bharath $K P$, Revathy $V$, Poornima S, Subba reddy VV. Dentigerous cyst in an uncommon site: a rare entity. J Indian Soc Pedod Prev Dent. 2011 Dec;29(6 Suppl 2):S99-103. doi: 10.4103/09704388.90756.

16. Puacz P, Koczorowski M, Kaczmarek I, Osmola K. Dentigerous cyst associated with maxillary canine as a reason of occlusion defect case report of 7 year old boy. Dev Period Med. 2013;12(1):72-76.

17. Yu-hsuan hu, Chang $\mathrm{YL}$, Tsai A. Conservative treatment of dentigerous cyst associated with primary teeth. Oral Surg Oral Med Oral Pathol Oral Radiol Endod. 2011 Dec;112(6):e5-7. doi: 10.1016/j.tripleo.2011.03.041

18. Amin ZA, Amran M, Khairudin A. Removal of extensive maxillary dentigerous cyst via a Caldwell-Luc procedure. Arch Orofac Sci. 2008;3(2):48-51.

19. Damante JH, Guerra ENS, Ferreira OJR. Spontaneous resolution of simple bone cysts. Dentomaxillofac Radiol. 2002 May;31(3):182-6. doi: 10.1038/sj/dmfr/4600696

20. Neville BW, Damm DD, Allem CM, Bouquot JE. Patologia oral e maxilofacial. $3^{\mathrm{a}}$ ed. Rio de Janeiro: Elsevier; 2009.

21. Shokier HM, Khalifa GA. Assessment of bone healing in large bony defects after enucleation of jaw cysts without using any graft material using direct digital radiography and CT scan. Cairo Dent J. 2009;25(1):35-42.

22. Tüzüm MS. Marsupialization of a cyst lesion to allow tooth eruption: a case report. Quintessence Int. 1997 Apr;28(4):283-4.

Received on: $16 / 7 / 2017$

Final version resubmitted on: 3/11/2017 Approved on: 11/11/2017 